\title{
Consumer Perceptions of Branding Alliances of Educational Institutions and Hotels in Hong Kong
}

\author{
Kiki Oy-Lar Chan $^{1} \&$ Soo-May Cheng ${ }^{2}$ \\ ${ }^{1}$ Hong Kong Community College, The Hong Kong Polytechnic University, Hong Kong, China \\ ${ }^{2}$ Faculty of Hospitality and Tourism Management, Macau University of Science and Technology, Macau, China \\ Correspondence: Kiki Oy-Lar Chan, Hong Kong Community College, The Hong Kong Polytechnic University, \\ 9 Hoi Ting Road, Yau Ma Tei, Hong Kong, China. Tel: 852-3746-0332. E-mail: cckiki@hkcc-polyu.edu.hk \\ Received: September 10, 2012 Accepted: September 24, 2012 Online Published: October 23, 2012 \\ doi:10.5539/ijbm.v7n21p92 URL: http://dx.doi.org/10.5539/ijbm.v7n21p92
}

\begin{abstract}
The purpose of this study is to examine how potential customers (students) of tertiary educational institutions perceive the co-branding of such institutions with hotels. This study is an attempt to provide useful insights into the variables that influence evaluation of brand alliances in service sectors, and to discuss implications for institutional and hotel reputation building. Quantitative data were collected from students of post-secondary colleges in Hong Kong by using self-administered questionnaires. Each participant was randomly assigned to one of the six alliances between tertiary educational institution brands and hotel brands. The findings suggest that consumer pre-attitudes toward brand partners and perceived brand fit are positively related to consumer evaluations of the brand alliance. In addition, brand familiarity is found to be important in moderating the relationship between perceived brand fit and consumer evaluations of the brand alliance. This study gives an additional empirical research into brand alliances in service sectors. Future research could also consider evaluating brand alliances from the perspectives of hotel customers. Marketers must carefully consider consumer perceptions of fit and the importance of brand familiarity when seeking allied partners. This study breaks from the ranks of strategic management studies of alliances focusing on the views of managers, to examine brand alliances from the customer perspective. Moreover, it has bridged the gaps between various management and marketing disciplines, showing the applicability of product branding concepts to service branding and institutional reputation building contexts.
\end{abstract}

Keywords: brand alliance, brand fit, brand familiarity, corporate reputation, education-hotel co-branding, service branding, Hong Kong

\section{Introduction}

Brand alliances between educational institutions and hotels have been increasing rapidly in recent years. Rigorous hotel construction has raised competition in the hotel sector, and hotel training schools have responded with equally energetic competition for students. These two trends have dovetailed into interdependence between hotels and educational institutions, and an increased appreciation of the potential of brand alliance strategies. Participating hotels can benefit from research outputs and innovative ideas they can use in their businesses, while educational institutions can benefit from having a better understanding of the industry's needs and giving their students opportunities to gain practical research experience in a real business environment.

Moreover, brand alliance strategies build competitive advantages through offering customers greater assurance about product quality than what a single-branded product can offer. Such strategies highlight the value of leveraging favourable brand equity, reducing costs and risks associated with the co-branding, increasing customer spending levels, and improving consumer attitudes toward the original brand as well as the alliance (Aaker, 1991; Aaker \& Keller, 1990; Liu et al., 2012; Simonin \& Ruth, 1998; Washburn, Till, \& Priluck, 2000).

On the downside, a number of researchers have raised concerns that brand alliances could hurt the reputations and images of partner brands (e.g., Cornelis, 2010; Farquhar, 1994). Risk is high when both brands are featured on the product and, therefore, an alliance product's failure can dilute the original brands' equity and reputation (Roedder, Loken, \& Joiner, 1998). If the association between the two partner brands of an alliance creates some confusion among consumers, it could affect the images of both brands (Park, Jun, \& Shocker, 1996).

Given the current trends in cooperation between education providers and the hotel industry, it is important to understand the perceived value of brand alliances. The difficulty of measuring corporate brand value, as opposed 
to product brands, remains a challenge for researchers and practitioners. When judgment is assailed by a heady mix of identity, image and communication, the corporate-watcher is hardly able to decide where to place his patronage or his investment. Hotels employ star- and diamond-rating systems for market positioning, symbolically representing a collection of tangible and intangible service offerings. Universities dance to the ranking efforts of ubiquitous agencies, financial institutions, and quality assurance bodies based on loosely agreed criteria like learning and research resources and outcomes. Standifird (2005) found several institutional features like a university's research emphasis, prior ranking, student size, and sports team performance to be influential in students' rating of American universities. But little is known about how they may fare when they are branded across sectors. From the perspective of educational institutions' consumers (students), what would influence their perception of the value of co-branding between an institution and a hotel? Answering this question is expected to reveal branding strategies that may enable institutions to build their corporate brands.

Hence this article reports a study of consumer evaluations of brand alliances between tertiary educational institutions and hotels. Specifically, the purpose of this study was to examine the effects of (1) prior consumer attitudes toward tertiary educational institution brands, (2) prior consumer attitudes toward hotel brands, (3) perceived brand fit and (4) brand familiarity, on tertiary educational institution and hotel alliances.

\section{Literature Review}

\subsection{Brand Alliance Theories}

The information integration theory describes how attitudes or beliefs are formed and modified as consumers receive, interpret, evaluate and then integrate information with existing beliefs or attitudes (Anderson, 1981). This theory provides theoretical support, suggesting that consumer pre-attitudes toward partner brands will be integrated with new information provided by an alliance, thus affecting consumer attitudes toward the brand alliance (Lafferty \& Goldsmith, 2003). When one brand is presented in the context of the other brand in a brand alliance, or vice versa, consumer evaluations of the brand alliance are likely to be influenced by pre-attitudes toward each partner brand (Simonin \& Ruth, 1998). This theory also explains how consumers evaluate brand fit when two partner brands are presented in a brand alliance (Bluemelhuber, Carter, \& Lambe, 2007; Simonin \& Ruth, 1998). A lack of fit between partner brands can result in a negative attitude toward the alliance (Lafferty, Goldsmith, \& Hult, 2004).

The attitude accessibility theory suggests consumers are more likely to access brand attitudes that are more salient (Fazio, 1986). In other words, the easier it is to retrieve a cue from memory, the more likely consumers will form an attitude about it (Fazio, Powell, \& Williams, 1989). This theory suggests that evaluations of a brand are retrieved automatically and transferred to the brand alliance product if consumers develop brand associations through a confrontation with a stimulus, such as excellent product quality of the brand (Helmig, Huber, \& Leeflang, 2007). Hence, if consumers' pre-attitudes toward individual partner brands are positive, they will adjust their attitudes toward the brand alliance and positively evaluate the brand alliance products accordingly (Helmig, et al., 2007; Lafferty \& Goldsmith, 2003). Moreover, a partner brand which is more familiar than the other has a stronger influence on attitudes toward the brand alliance (Simonin \& Ruth, 1998) because consumers will bias information processing in a direction toward the more familiar brand (Fazio, 1986; Fazio, et al., 1989).

\subsection{Prior Brand Attitudes}

A brand alliance is influenced by brand attitudes before the alliance is formed (Simonin \& Ruth, 1998). More specifically, any form of brand alliance is conducted in an attempt to transfer positive attitudes from individual brands to a new brand alliance offering. The more favourable prior attitudes toward individual partner brands are, the more positive will evaluations of a brand alliance be received from consumers (Dickinson \& Barker, 2007).

\subsection{Perceived Brand Fit}

Perceptions of fit have important implications for brand alliance evaluations (Bouten, Snelders, \& Hultinkand, 2011; Lanseng \& Olsen, 2012). If there is an overall consumer perception of fit between two individual partner brands on the basis of either product category or brand concept consistency, the positive associations that the consumer holds toward each individual partner brand can be transferred to the brand alliance offering (Dickinson \& Heath, 2006, 2008). According to Simonin and Ruth's (1998) study, if two allying brands are perceived to have good fit, the alliance will be evaluated more favourably than if the two brands are seen as incompatible. More importantly, perceived brand fit exerts positive influences on consumer purchase intention (Ashton \& Scott, 2011). 


\subsection{Brand Familiarity}

Brand familiarity reflects consumers' direct or indirect experience of the brand (Alba \& Hutchinson, 1987), such as advertising exposures, interactions with salespersons, word-of-mouth communications, trial and consumption. As familiarity increases, cognitive effort required to process the product-related information decreases. Even without specific product knowledge, consumers may use brand familiarity as a criterion to determine product choice (Hoyer \& Brown, 1990), reduce perceived risk ( K. Keller, 1993), vary brand associations (Low \& Lamb, 2000), and affect consumer evaluations of co-branding partners (Guillet \& Tasci, 2010).

There are three different levels of familiarity to determine how much a person thinks he knows about a product. Low familiarity occurs when consumers do not have prior product-usage experience, relevant product knowledge or information about brand differences and functional product attributes, and do not own the product; moderate familiarity occurs when people have some product-usage experience, and some relevant information but do not currently own the product; and high familiarity occurs when people have relevant product knowledge and currently own the product (Park \& Lessig, 1981). Different levels of familiarity may affect consumer attitudes: the more familiar consumers are with the product, the stronger are their attitudes toward the product (Fazio, et al., 1989).

Brand familiarity plays a moderating role in the effect of brand fit on consumer evaluations of brand alliance. When there is a less familiar brand in an alliance, the effect of brand fit on brand alliance evaluation is reduced; but when a highly familiar brand is there in an alliance, the effect of brand fit on brand alliance evaluations is increased (Simonin \& Ruth, 1998).

\subsection{Dimensions for Evaluating Brand Alliance}

Brand associations play an important role in understanding how consumers evaluate brand alliance (Dickinson $\&$ Heath, 2006, 2008). Consumers use brand associations when processing, organizing, and retrieving information from memory, and when making purchase decisions (Aaker, 1991). Three brand associations linked in memory to a brand are brand image, brand attitude and perceived quality (Low \& Lamb, 2000).

Brand image refers to the overall reputation and perception of a brand (Zeithaml, 1988). A favourable brand image constitutes a competitive advantage for a company (Aaker, 1990). Brand image consists of attributes and associations that consumers relate to a brand, and these can be either tangible, functional attributes of the brand, or emotional-based attributes of the brand (Biel, 1991). Consumers are likely to incorporate information related to the brand image into their purchase decisions and assessment of brands (Lafferty \& Goldsmith, 1999). Ultimately, firms engaging in a brand alliance expect to receive benefits such as additional market exposure and enhancement of the reputation of their own brand by being allied with a respected partner brand (Dickinson \& Heath, 2006).

Brand attitudes can be defined as consumers' overall evaluations of a brand (Mitchell \& Olson, 1981). Consumers might form an attitude based on their direct experience (Fazio, 1986) or their imagined attempt to experience the attitude object (P. Keller \& McGill, 1994). In general, consumers are more likely to select a brand toward which they hold the most favourable attitude when facing a choice of brands in a product category (James, 2005). A favourable attitude not only builds a strong brand and helps consumer decision making, but also helps the brand overcome attacks or other offensive actions from its competitors (Haugtvedt, Leavitt, \& Schneier, 1993).

Perceived quality is consumer's judgment about the overall excellence or superiority of a product (Zeithaml, 1988). Previous studies show in the contexts of a brand alliance that brands with high perceived quality perform better when leveraged in a new product situation (Aaker \& Keller, 1990; Rao \& Ruekert, 1994). Consumers' perceptions of quality may be enhanced when a second brand name (i.e. allied partner brand name) is provided for a product that has unobservable product attributes (Rao, Qu, \& Ruekert, 1999).

Apart from the abovementioned three brand associations, it is also important to assess purchase intention in order to more completely capture consumer evaluations (Dickinson \& Heath, 2008). Previous studies show that brand and purchase intention are highly related. Consumers place more emphasis on brand reputation when making purchase decisions for less tangible services (e.g. investment services) compared to more tangible services (e.g. hotel) and tangible goods (e.g. computer) (Brady, Bourdeau, \& Heskel, 2005). In the context of a brand alliance, attitudes toward the brand alliance are related positively to purchase intentions (Rodrigue \& Biswas, 2004). Overt purchase behaviour toward the brands is largely a function of the buyer's purchase intentions, which in turn is largely a function of the buyer's attitudes toward the brands or the overall evaluation of the brands (Bennett \& Harrell, 1975; Rodrigue \& Biswas, 2004). 
This study has integrated these four dimensions (i.e. brand image, brand attitude, perceived quality, and purchase intention) as the drivers of consumer evaluations of brand alliances.

\subsection{Services and Brand Alliances}

Consumers depend on extrinsic attributes more than intrinsic attributes in initial purchase situations, when evaluation of intrinsic cues requires more effort and time than consumers perceive worthwhile, and when quality is difficult to evaluate (Boulding, Kalra, Staelin, \& Zeithaml, 1993). Brand plays a special role in service sectors (Berry, 2000). Some researchers have even agreed that brand is more important for services than for goods (e.g., Onkvisit and Shaw (1989)). Hence, building branding effects, such as brand awareness and brand image, for service firms is absolutely crucial. Strong brands can help reduce risks associated with the purchase and consumption of many services, and can help consumers better understand and visualize what they are buying (Bharadwaj, Varadarajan, \& Fahy, 1993).

In the knowledge-based era, an educational institution provides human capital and knowledge to firms. Corporations nowadays anticipate that more of their sales and revenue growth must come through the innovation and introduction of new products and processes (Ali, 1994). Consequently, there is a closer linkage between industries and academic institutions to stimulate technology transfer opportunities such as addressing specific research problems, providing technical expertise for developing new products, assisting business set-ups, and providing patents or licensing services (Santoro, 2000).

In Hong Kong, The Chinese University of Hong Kong is collaborating with the New World Development Company (the owner of New World Hotels) to set up a four-star teaching hotel for improving the service quality of the hospitality industry (The Chinese University of Hong Kong, 2001). The Hong Kong Polytechnic University's School of Hotel and Tourism Management and the Banyan Tree Hotels and Resorts agree to collaborate on executive education, research and internship programmes (Banyan Tree Hotels and Resorts, 2011). Other educational institutions have partnered with the Hong Kong Hotels Association to enhance industry education and training and to undertake research programmes so as to increase the competitiveness of the hospitality industry (Hong Kong Hotels Association, 2009). These and other examples of cross-sector branding alliances, plus the relentless paper-chase amongst students for higher qualifications, render Hong Kong a dynamic research site for the reported study.

\section{Conceptual Framework and Research Hypotheses}

This study suggests that consumer evaluations of brand alliance are influenced by prior consumer attitudes toward brands and consumer perception of fit between two partner brands, with brand familiarity as a moderating factor. Furthermore, the four dimensions of brand image, brand attitude, perceived quality, and purchase intention are used as indicators of consumer evaluations of brand alliances. Figure 1 is the framework of research showing the hypothesized relationships.

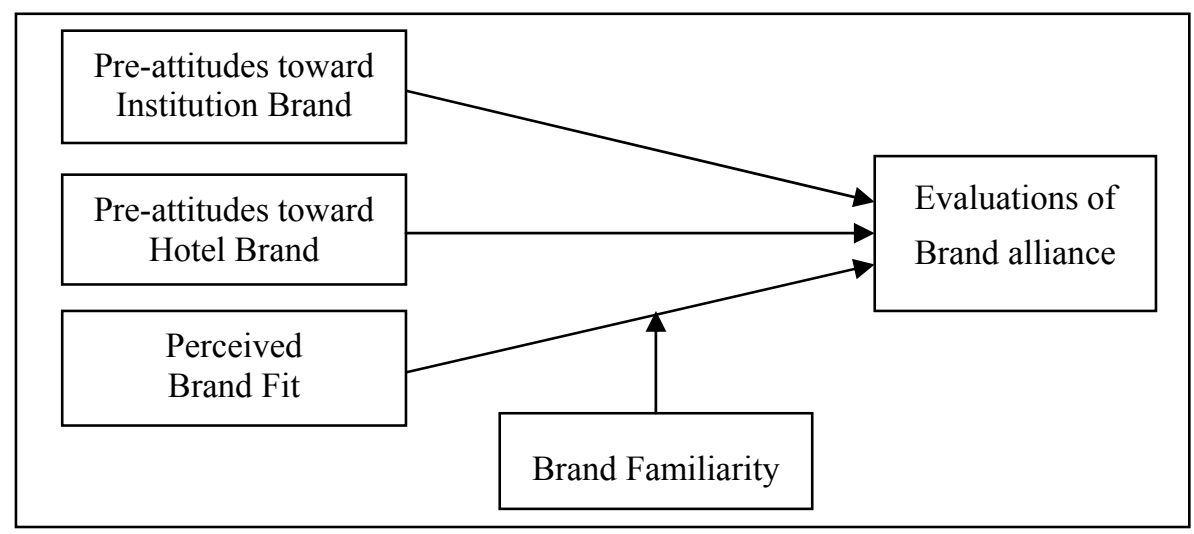

Figure 1. Research framework

If prior consumer attitudes are positive, then the overall evaluation of the brand alliance tends to be positive. If prior consumer attitudes are negative, then the overall evaluation of the brand alliance is usually negative (Simonin \& Ruth, 1998). Dickinson and Barker (2007) also agreed that the more favourable prior consumer' attitudes are toward the individual partner brands, the more positive evaluations the brand alliance will receive. 
Thus, two hypotheses are derived as follows:

Hypothesis H1: Pre-attitudes toward tertiary educational institution brand are positively related to consumer evaluations of the brand alliance.

Hypothesis H2: Pre-attitudes toward hotel brand are positively related to consumer evaluations of the brand alliance.

When two brand images are perceived to be inconsistent with each other, consumers question why the two brands are allied and the alliance will lead to undesirable beliefs and judgements (Simonin \& Ruth, 1998). When two brand images are perceived to be consistent, an alliance will create positive consumer attitudes toward the brand alliance product (Helmig, et al., 2007; James, 2005). Thus, it is expected that the more two brand images are perceived to be consistent with each other, the more positive evaluations their brand alliance will receive from consumers. The third hypothesis is derived as follows:

\section{Hypothesis H3: Perceived brand fit is positively related to consumer evaluations of the brand alliance.}

Prior studies (e.g., Hoyer \& Brown, 1990; Johnson \& Russo, 1984) show that consumers having a high degree of familiarity with products evaluate them differently from those who are less familiar. Hence brand familiarity may exert a moderating influence on the relationship between brand fit and brand alliance evaluation (Simonin \& Ruth, 1998). Low familiarity may lead to lower evaluation of their alliance despite perceived brand fit. In contrast, high familiarity may lead to perception of a stronger brand fit and higher alliance evaluation. The fourth hypothesis is thus derived as follows:

Hypothesis H4: The relationship between perceived brand fit and consumer evaluations of the brand alliance is moderated by brand familiarity.

\section{Method}

\subsection{Research Design and Methodology}

A quantitative research study using self-administered questionnaire was adopted. The research was conducted in classrooms of two educational institutions. Prior to the main study, a pretest was conducted to identify different hotel brands and educational institution brands with distinct levels of brand familiarity. Subsequently, in the main study, the brands were paired and subjected to brand alliance evaluation by clusters of respondents assigned randomly to each pair of brand allies.

\subsection{Samples and Sampling Technique}

The participants were students randomly recruited from two Hong Kong post-secondary educational institutions offering hospitality-related programmes. They represented the population of students who were being courted by universities to matriculate into the latter's Bachelor degree programmes in hotel or hospitality management. The pretest had 124 participants while the main study received 479 out of 514 questionnaires.

\subsection{Data Collection}

\subsubsection{Pretest: Selection of Brands}

This stage served its function by identifying the hotel brands and institution brands that have high levels of familiarity to be used within the main study. The participants were asked to name the best and the worst hotels in Hong Kong by their reputation. They were also asked to name the best and the worst Hong Kong educational institutions offering Bachelor-degree hospitality programmes.

The highest percentage of participants identified The Peninsula Hong Kong (hereinafter referred to as Peninsula) as the "best" hotel (68\%) and Bridal Tea House Hotel (hereinafter referred to as Bridal) as the "worst" hotel $(40 \%)$. As this was a perceptual study, participants' opinions as shaped by advertising, word-of-mouth, media coverage, and industry news were acceptable. Their familiarity with these brands would later be tested as a critical factor influencing customer evaluation of paired brand alliances. Simultaneously, The Chinese University of Hong Kong (hereinafter referred to as CU) was selected as the "best" institution (60\%) and Caritas Bianchi College of Careers (hereinafter referred to as CBC) as the "worst" institution (41\%) by the highest percentage of participants. Such market positions as perceived by the participants are probably influenced by a combination of experience, exchange of news and views among university students, and media reports. 


\subsubsection{Main Study: Evaluation of Alliances}

Next, the ranked list of hotels and educational institutions were paired thus: each of two institutions (CU and CBC) with each of three hotels (Peninsula, Bridal and Hacton) making six pairs. A fictitious brand, Hacton Hotel, was added to secure a low level of brand familiarity among participants as a contrast to the well-known brands. Fictitious brands are usually used in brand association studies to heighten experimental control (Boush \& Loken, 1991; Keller \& Aaker, 1992). These pairs of allied brands were then used as the focus of a pre-designed questionnaire administered to a larger cross-sectional sample of Hong Kong students enrolled in post-secondary hospitality-related programmes.

The first section of the questionnaire consisted of a set of questions about pre-attitudes toward and familiarity with both partner brands, as well as brand fit perceptions. The second section was a stimulus print advertisement used to give respondents a brief description of the alliance, which fictitiously announced the launch of a joint bachelor degree programme. The advertisement was designed in its preliminary stages of development sans creative artwork in order to minimize the effect of advertisement-based evaluation by the respondents (Bluemelhuber, et al., 2007). After reading the print advertisement, respondents were asked to evaluate the brand alliance in terms of (1) their overall attitudes toward the alliance, (2) considerations for applying for the degree programme, (3) overall service quality perception, and (4) overall brand image of the alliance.

\subsection{Measurement Instrument}

All constructs assessed through seven-point bipolar semantic differential scales had already been evaluated by the original authors. The questions for measuring brand attitude were adapted from Low and Lamb (2000), perceived brand fit and brand familiarity from Simonin and Ruth (1998), and evaluations of brand alliance from Dickson and Heath (2008), Kwun and Oh (2007), Low and Lamb (2000) and Simonin and Ruth (1998).

\section{Results}

\subsection{Participant Characteristics}

A very high response rate $(91.2 \%)$ was achieved when 479 usable questionnaires were received out of 514 sent out. The sample profile comprised $71 \%$ female students; $73 \%$ associate degree students, $14 \%$ foundation-year undergraduate students and $13 \%$ higher diploma students.

\subsection{Factor Analysis for Construct Validity}

Principle component analysis with Varimax rotation was conducted for measuring six constructs in the main study questionnaire. The result showed the constructs had sufficiently strong loadings on appropriate components ranged from 0.755 to 0.929 , according to the cut-off factor loadings of 0.50 as recommended by Hair, Anderson, Tatman and Black (2010).

\subsection{Cronbach's Alpha for Reliability Testing}

The reliability coefficients of the six constructs ranged from 0.88 to 0.98 as shown in Table 1 . Cronbach's alpha of reliability is 0.97 for pre-attitudes toward hotel brand, 0.97 for pre-attitudes toward institution brand, 0.95 for perceived brand fit, 0.98 for hotel brand familiarity, 0.88 for institution brand familiarity, and 0.97 for evaluations of brand alliance, indicating that the multiple items consistently measured the purported constructs in all cases. Brand alliance attitude has the highest mean of 4.75 , followed by brand alliance image 4.65 , perceived brand alliance quality 4.59 , and likelihood of applying for the degree programme 4.47 .

Table 1. Item-specific descriptive statistics and reliability

\begin{tabular}{llccc}
\hline \multicolumn{1}{c}{ Constructs } & \multicolumn{1}{c}{ Item } & Mean & S.D. & Reliability \\
\hline Hotel brand familiarity & familiar/unfamiliar & 3.34 & 2.15 & 0.98 \\
& recognized/did not recognize & 3.47 & 2.23 & \\
& had heard of/had not heard of & 3.67 & 2.42 & \\
Hotel brand pre-attitude & positive/negative & 4.24 & 1.55 & 0.97 \\
& pleasant/unpleasant & 4.16 & 1.52 & \\
& valuable/worthless & 4.13 & 1.54 & \\
Institution brand familiarity & familiar/unfamiliar & 6.07 & 1.00 & 0.88 \\
& recognized/did not recognize & 6.22 & 0.88 & \\
& had heard of/had not heard of & 6.35 & 0.88 & \\
Institution brand pre-attitude & positive/negative & 4.99 & 1.38 & 0.97 \\
\hline
\end{tabular}




\begin{tabular}{lllll}
\hline & pleasant/unpleasant & 4.92 & 1.37 & \\
& valuable/worthless & 4.97 & 1.43 & \\
Brand fit & is/is not consistent & 4.12 & 1.35 & 0.95 \\
& is/is not complementary & 4.04 & 1.29 & \\
Evaluation of Brand Alliance & is/is not similar & 3.80 & 1.37 & \\
Brand alliance attitude & positive/negative & 4.80 & 1.22 & 0.97 \\
& pleasant/unpleasant & 4.72 & 1.20 & \\
Likely to apply for the program & valuable/worthless & 4.72 & 1.26 & \\
Perceived brand alliance quality & very likely/not at all likely & 4.47 & 1.45 & \\
& superior/inferior & 4.56 & 1.18 & \\
& favourable/unfavourable & 4.60 & 1.22 & \\
Brand alliance image & good/bad & 4.60 & 1.19 & \\
& favourable/unfavourable & 4.67 & 1.26 & \\
& good/bad & 4.63 & 1.28 & \\
\hline
\end{tabular}

\subsection{Bivariate Inter-item Correlations}

Aninter-item correlation matrix was constructed to reveal the average within- and between-construct correlations among the individual measuring items. Table 2 indicates that there is convergence among the items used to measure the same construct. Moreover, items do not correlate too highly with the measures from which they are supposed to be different. As a result, these correlation results provide the evidence of convergent and discriminant validities (Campbell \& Donald, 1959). Therefore, the within-construct items were used in the subsequent analyses by averaging the scores of the items of each construct.

Table 2. Within and between-construct correlation matrix

\begin{tabular}{|c|c|c|c|c|c|c|}
\hline & $\begin{array}{c}\text { Pre-attitudes } \\
\text { toward hotel } \\
\text { brand }\end{array}$ & $\begin{array}{c}\text { Pre-attitudes } \\
\text { toward } \\
\text { institution } \\
\text { brand }\end{array}$ & $\begin{array}{l}\text { Perceived } \\
\text { brand fit }\end{array}$ & $\begin{array}{l}\text { Hotel brand } \\
\text { familiarity }\end{array}$ & $\begin{array}{l}\text { Institution } \\
\text { brand } \\
\text { familiarity }\end{array}$ & $\begin{array}{c}\text { Evaluations } \\
\text { of brand } \\
\text { alliance }\end{array}$ \\
\hline $\begin{array}{l}\text { Pre-attitudes toward hotel } \\
\text { brand }\end{array}$ & 0.92 & & & & & \\
\hline $\begin{array}{ll}\text { Pre-attitudes } & \text { toward } \\
\text { institution brand } & \end{array}$ & 0.17 & 0.92 & & & & \\
\hline Perceived brand fit & 0.38 & 0.38 & 0.86 & & & \\
\hline Hotel brand familiarity & 0.70 & 0.08 & 0.30 & 0.95 & & \\
\hline Institution brand familiarity & 0.00 & 0.22 & 0.01 & 0.06 & 0.71 & \\
\hline Evaluations of brand alliance & 0.43 & 0.43 & 0.55 & 0.33 & 0.11 & 0.77 \\
\hline Mean & 4.18 & 4.96 & 3.99 & 3.49 & 6.21 & 4.64 \\
\hline S.D. & 1.50 & 1.35 & 1.27 & 2.23 & 0.83 & 1.11 \\
\hline
\end{tabular}

Note: Entries in bold fonts are within-construct correlations

The means and standard deviations showed that institution brand familiarity is uniformly high (Mean $=6.21$, S.D. $=0.83$ ) while hotel brand familiarity is variable $($ Mean $=3.49$, S.D. $=2.23$ ). In other words, respondents were more familiar with tertiary educational institution brands than hotel brands. There are two possible reasons. First, in Hong Kong, there are only 13 tertiary educational institutions offering hospitality-related programmes, whereas there are more than 170 hotels across different districts. Second, the respondents of this study were 
Hong Kong students studying in the post-secondary educational institutions. Hence, the respondents should be more familiar with tertiary educational institution brands than hotel brands. Following Simonin and Ruth's (1998) methodology, different levels of brand familiarity with hotel were then used to assess brand familiarity's moderating effect in the model.

\subsection{Hypothesis Testing}

To test the hypotheses, correlation analyses were conducted across the six brand alliances relating to pre-attitudes toward brands, brand fit and brand alliance evaluations. The results revealed that consumer evaluations of the brand alliance are significantly and positively correlated with pre-attitudes toward tertiary educational institution brand $(\mathrm{r}=0.50, \mathrm{p}<0.01)$, pre-attitudes toward hotel brand $(\mathrm{r}=0.50, \mathrm{p}<0.01)$, and perceived brand fit $(r=0.65, \mathrm{p}<0.01)$. Hence, Hypotheses $1-3$ are supported.

Further multivariate regression analysis was conducted to examine whether pre-attitudes towards brands, brand fit and brand familiarity have unique effects on consumer evaluations of the brand alliance as shown in Table 3 . This analysis revealed that brand fit $(b=0.36, p<0.01)$, pre-attitudes toward institution brand $(b=0.23, p<$ $0.01)$, and pre-attitude toward hotel brand $(b=0.19, p<0.01)$ have significant unique whereas brand familiarity does not $(b=0.02, p>0.01)$ further supporting Hypotheses 1-3. It is understandable that brand familiarity does not have a significant effect on consumer evaluation of the brand because it was proposed as a moderator in the study. Moreover, brand fit, pre-attitudes toward institution brand, pre-attitudes toward hotel brand and brand familiarity together explain $55 \%$ of the variance in consumer evaluations of the brand alliance (i.e. R-square $=$ $0.55)$. The amount of explained variance is significant $\{F(4,474)=143.23, p<0.01\}$. The results also showed that brand fit is the predictor of consumer evaluations of the brand alliance because it has the largest beta value (i.e. 0.42 ).

Table 3. Multivariate regression analysis

\begin{tabular}{|c|c|c|c|c|c|c|c|c|}
\hline \multicolumn{2}{|l|}{ Model } & $\begin{array}{c}\text { Unstandardised } \\
\text { estimate (b) }\end{array}$ & $\begin{array}{c}\text { Standard } \\
\text { error }\end{array}$ & $\begin{array}{c}\text { Standardized } \\
\text { estimate } \\
\text { (Beta) }\end{array}$ & t-value & p-value & F-value & p-value \\
\hline $\begin{array}{l}\text { Pre-attitudes } \\
\text { hotel brand }\end{array}$ & toward & .185 & .035 & .249 & 5.281 & .000 & 143.2381 & .000 \\
\hline $\begin{array}{l}\text { Pre-attitudes } \\
\text { institution brand }\end{array}$ & toward & .233 & .028 & .282 & 8.299 & .000 & & \\
\hline Perceived brand & & .363 & .032 & .415 & 11.303 & .000 & & \\
\hline Hotel brand fami & iarity & .019 & .023 & .039 & .853 & .394 & & \\
\hline
\end{tabular}

A Dependent Variable: consumer evaluations of the brand alliance

Whether the relationship between perceived brand fit and consumer evaluations of the brand alliance is moderated by brand familiarity was tested by hierarchical regression analysis with the procedure proposed by Baron and Kenny (1986). The hierarchical regression analysis revealed that brand familiarity moderates the relationship between perceived brand fit and consumer evaluations of the brand alliance. Table 4 shows that the product-term (i.e. Brand fit $\mathrm{x}$ Hotel familiarity) is $\mathrm{b}=0.08, \mathrm{p}<0.05$.

Table 4. Hierarchical regression analysis on moderator

\begin{tabular}{lccccc}
\hline \multicolumn{1}{c}{ Model } & $\begin{array}{c}\text { Unstandardised } \\
\text { estimate (b) }\end{array}$ & $\begin{array}{c}\text { Standard } \\
\text { error }\end{array}$ & $\begin{array}{c}\text { Standardized } \\
\text { estimate (Beta) }\end{array}$ & t-value & p-value \\
\hline Brand Fit & .640 & .040 & .575 & 15.915 & .000 \\
Hotel Familiarity & .210 & .040 & .188 & 5.270 & .000 \\
Brand Fit×Hotel Familiarity & .075 & .036 & .072 & 2.088 & .037 \\
\hline
\end{tabular}

A Dependent Variable: consumer evaluations of the brand alliance 
Table 5 shows that the magnitude of the moderation effect is 0.005 (i.e. $0.005=0.455-0.450$ ) which is referred to as the change in R-square caused by the moderation effect. Hence, Hypothesis 4 is supported.

Table 5. R-square and R-square change

\begin{tabular}{lcc}
\hline & $\mathbf{R}^{2}$ & $\Delta \mathbf{R}^{2}$ (Change R2) \\
\hline $\mathrm{BF}$ & .418 & .418 \\
$\mathrm{BF}+\mathrm{HF}$ & .450 & .032 \\
$\mathrm{BF}+\mathrm{HF}+\mathrm{BFHF}$ & .455 & .005 \\
\hline
\end{tabular}

Note: $\mathrm{BF}=$ BrandFit, $\mathrm{HF}=$ HotelFamiliarity, $\mathrm{BFHF}=$ BrandFit $\mathrm{x}$ HotelFamiliarity

To more closely examine the moderation effect, brand familiarity was divided into three groups (i.e. low ( $33^{\text {rd }}$ percentile), medium $\left(67^{\text {th }}\right.$ percentile), and high $\left(>67^{\text {th }}\right.$ percentile)). The correlation between brand fit and consumer evaluations of the brand alliance is considerably larger for higher brand familiarity (i.e. $(\mathrm{r}=0.49, \mathrm{p}<$ $0.01)$ ) for low brand familiarity, $(\mathrm{r}=0.61, \mathrm{p}<0.01)$ for medium brand familiarity, and $(\mathrm{r}=0.71, \mathrm{p}<0.01)$ for high brand familiarity) as show in Table 6. Specifically, this pattern of correlations revealed that the effect of brand fit on consumer evaluations of the brand alliance is smaller when brand familiarity is low, whereas the effect of brand fit on consumer evaluations of the brand alliance is larger when brand familiarity is higher.

Table 6. Correlations between brand fit and consumer evaluations of brand alliance under varying degrees of brand familiarity

\begin{tabular}{lc}
\hline \multicolumn{1}{c}{ Degree of Brand Familiarity } & Correlations \\
\hline Low $\left(33^{\text {rd }}\right.$ percentile $)$ & $.493^{* *}$ \\
Medium $\left(67^{\text {th }}\right.$ percentile $)$ & $.606^{* *}$ \\
High $\left(>67^{\text {th }}\right.$ percentile $)$ & $.710^{* *}$ \\
\hline
\end{tabular}

**. Correlation is significant at the 0.01 level (1-tailed)

\section{Discussion}

The results of this study provide useful insights into branding effects on brand alliances between tertiary educational institutions and hotels. The findings show that pre-attitudes toward partner brands and perceived brand fit have important influence on consumer evaluations of the brand alliance. These results suggest that a beneficial brand partner not only causes a brand to be evaluated favourably by customers, but also produces favourable perceptions of brand fit. Such brand fit perceptions, subsequently, are even more important than attitudes towards individual partner brands when consumers evaluate the alliance. These results are consistent with previous brand extension and brand alliance studies which indicate consumers' prior brand attitudes towards partner brands and perceptions of brand fit related positively to evaluations of brand extension and brand alliance (e.g., Aaker \& Keller, 1990; Simonin \& Ruth, 1998). The more favourable prior attitudes toward individual partner brands are, the more positive evaluations of the brand alliance by consumers will be (Dickinson \& Barker, 2007), and when the overall perception of two brands is fit, their alliance will be evaluated more favourably than when the two brands are seen to be inconsistent and incompatible (Simonin \& Ruth, 1998).

The moderating effect of brand familiarity was found to play a key role in understanding consumer evaluations of the brand alliance. Consistent with the theories of information integration and attitude accessibility, a partner brand that is more salient exerts a relatively greater effect on consumer evaluations of the brand alliance. These results are also in line with Simonin and Ruth's findings (1998). When one of the partner brands enjoys high brand familiarity, perceptions of brand fit exert a relatively strong influence on consumer evaluations of the 
brand alliance. Under conditions of low familiarity, evaluations of perceived brand fit are difficult because of weak association. Hence, when one of the partner brands has low brand familiarity, the effect of perceived brand fit on brand alliance evaluations is reduced.

This study has expanded on what has been previously reported in the brand alliance literature. Specifically, this study has used four dimensions for measuring consumer evaluations of brand alliance: brand attitude, purchase intention, perceived quality and brand image. In the brand alliance literature, no previous studies have used these four dimensions together as the indicators of consumer evaluations of brand alliances. Prior research had only used one or more dimensions, but not all of them together simultaneously. For example, Low and Lamb (2000) studied the three dimensions of brand associations including brand image, brand attitude, and perceived quality, and concluded that it is important for well-known brands to exhibit these three dimensions of brand associations. Simonin and Ruth (1998) revealed that prior attitudes toward the brands and perceived brand fit are positively related to attitudes toward the brand alliance. Dickinson and Heath (2006) suggested that perceived brand fit is associated positively with overall perceived quality of brand alliance and likelihood of trying the brand alliance products. The results of this study also demonstrated that the antecedents have the strongest impact on brand alliance attitude, followed by brand alliance image, and perceived brand alliance quality. However, they had the least impact on customers' likelihood to purchase (in other words, students' propensity to apply for study admission into institutions, regardless of which hotels they are paired with). This last finding may be explained by other factors not included in this study, such as fees, admission criteria, number of places offered, and the students' capability to meet those conditions.

\subsection{Theoretical Implications}

The results of this study provide evidence that consumers' prior attitudes toward the original brands exert a significant positive influence on consumer evaluations of a brand alliance. The implication of this finding is that a favourable attitude toward the brand is critical for positioning a brand alliance.

Consumers are more likely to have desirable and favourable attitudes toward the brand when the overall perception of the two brands is fit. Moreover, this research found that perceived brand fit has a more significant impact on brand alliance evaluations than attitudes toward the original brands. This finding implies that consumer perceptions of fit between two brands is important and has a stronger and more critical influence on consumer evaluations of a brand alliance than consumers' prior attitudes toward the brands.

The importance of perceived brand fit in the brand alliance was further supported by the introduction of a moderating variable (i.e. brand familiarity). The results of this study support that consumers who are highly familiar with the original brand are more likely to transfer their favourable evaluations from perceived brand fit to the brand alliance than those who are less familiar. The implication of this finding is that the transfer of a positive perception of brand fit to its brand alliance evaluation is facilitated by the level of familiarity that consumers have.

An understanding of the dimensions of brand alliance evaluation is valuable. This study has shown that it is important to assess brand attitude, purchase intention, perceived quality and brand image in order to more completely capture consumer evaluations of brand alliances.

Grounded in the marketing literature, a framework for research on brand alliance in the context of tertiary educational institutions and hotels in Hong Kong was developed specifically for this research. Previous studies have mainly concentrated on physical goods (e.g., Bluemelhuber, et al., 2007; Simonin \& Ruth, 1998), whereas this research has made an important step toward by examining brand alliance in the context of two service industries and has confirmed the generalisability of product branding concepts to service branding and institutional reputation contexts. Roberts and Dowling's (2002) evidence of the positive link between firms' reputation and financial performance is a further reminder that if other factors are equal students' positive perceptions of education-hotel brand alliances may translate into tangible rewards for the educational institutions seen to be co-branding with powerful hotel brands. Hence this study has contributed towards the blurring of the lines demarcating marketing, corporate relations and strategic management; such a cross-disciplinary overview is useful for real-world understanding of reputation-building.

Moreover, this research was conducted from the customers' (i.e. students') perspective. Traditionally, the literature on business alliances has almost exclusively reflected the views of managers and insider stakeholders. This study has shown that customers' assessment of the value of brand alliances should also be taken into account in such strategic moves. 


\subsection{Managerial Implications}

The results of this study have important implications for marketing managers of hotels and tertiary education institutions. The trend of forming brand alliance in service sectors is expected to continue due to increasing global and local competition. Brand positioning from a customer perspective is important because brand cues, such as brand image and brand attitude, that come from customers' perceptions of the brand may eventually affect consumers' purchase intentions. In order to improve brand image, brand attitude and perceived quality, and to maximize profits from a brand alliance, marketing managers need to clearly understand how consumers perceive their brand alliances. More importantly, experience-dominant services, such as hotel and education services, which have characteristics that customers can evaluate only after purchase or during use, are perceived by customers as riskier purchases than physical products. Marketing managers need to understand that favourable brand cues can reduce customers' perceived monetary, social or safety risks when buying services (Berry, 2000). Hence, it is crucial for the managements of hotels and educational institutions to allocate resources to marketing activities to achieve favourable brand associations in order to ensure competitive advantages in the marketplace.

The results of this study reveal that perceived brand fit has the strongest effect on consumer evaluations of the brand alliance, followed by consumers' prior attitudes toward the brands. With fragile customer loyalty and fierce competition, marketing managers need to develop marketing strategies that can improve consumer attitudes toward the brands, by ensuring that the images of the two partner brands fit together and thereby facilitate positive evaluations of brand alliances, rather than waiting for customers to make inferences about brand alliances.

In addition to the effects of perceived brand fit and consumer attitudes on a favourable evaluation of brand alliance, it is important to understand other attributes that may also influence the effectiveness and success of brand alliance. The findings of this study reveal that the impact of perceived brand fit on consumer evaluations of brand alliance increases as brand familiarity increases. In spite of this diminishing effect of brand fit due to the lower level of brand familiarity, better-known brands still might have an incentive to ally with less-known brands as long as the perceived brand fit is not detrimental (Simonin \& Ruth, 1998). In other words, these results are consistent with the notion of "free rider" that could develop for a less-known brand when it allies with a better-known brand (Simonin \& Ruth, 1998). Therefore, marketing managers of less-known hotel brands or tertiary educational institution brands should seek brands that are familiar to consumers when forming alliances. To avoid bloodletting in the over-crowded five-star hotel sector, Hong Kong educational institutions seeking brand partners may do well to consider the increasingly popular boutique hotels like JIA, Le Rivage and Hullet House which exude individualistic charm and offer unique service experiences. Such niche alliances may appeal to a young market of tertiary students.

\subsection{Limitation and Future Research}

Certain limitations inherent in this study need to be acknowledged and future studies are recommended accordingly. First, the type of services covered is limited. Other services were not taken into account in this research. There are three types of services: search-, experience- and credence-dominant services and they are embedded with different characteristics. Customers may have different expectations from different types of services. Therefore, it would be useful if future research relates to other types of services to determine whether the findings are generalisable.

Second, this research is limited to study of alliances between hotel brands and tertiary educational institution brands from the perspective of institutions' customers; it does not include customers of hotels. Studying responses of hotel customers may reveal different results. Future research may consider evaluating brand alliances from the perspective of hotel customers. It would be interesting to compare the responses from different types of customers. Similarly, it would be worthwhile to examine brand alliances from the perspectives of employers and employees of allied organizations for getting more insights about the effectiveness of brand alliances.

Third, this study is mainly focused on testing individual subjective judgements, such as consumer perceptions of consistency of two partner brands (i.e. brand fit) and consumer pre-attitudes toward the brand. Hence, it would be worthwhile for future studies to examine some strategic alliance factors such as cost benefits, technology and knowledge transfer opportunities, and environmental factors, such as the supply of hospitality graduates exceeding the demand from hotels and economic downturn depressing the hospitality sector.

Finally, the theoretical framework of this study should be regarded as a starting point toward a full integration of the effects of consumer evaluations of brand alliance on subsequent impressions of each partner brand. That is, it 
would be interesting for future studies to go deeper into consumers' post attitudes toward each of the partner brands after a brand alliance is formed.

\section{References}

Aaker, D. A. (1990). Brand extensions: the good, the bad, and the ugly. Sloan Management Review, 31(4), 47-56.

Aaker, D. A. (1991). Managing brand equity. New York: NY: The Free Press.

Aaker, D. A., \& Keller, K. L. (1990). Consumer evaluations of brand extensions. Journal of Marketing, 54(1), 27-41. http://dx.doi.org/10.2307/1252171

Alba, J. W., \& Hutchinson, J. W. (1987). Dimensions of consumer expertise. Journal of Consumer Research, 13(4), 411-454. http://dx.doi.org/10.1086/209080

Ali, A. (1994). Pioneering versus incremental innovation: review and research propositions. Journal of Product Innovation Management, 11(1), 46-61. http://dx.doi.org/10.1111/1540-5885.1110046

Anderson, N. H. (1981). Foundations of information integration theory. New York: Academic Press.

Ashton, A. S., \& Scott, N. (2011). Hotel restaurant co-branding: the relationship of perceived brand fit with intention to purchase. Journal of Vacation Marketing, 17(4), 275-285. http://dx.doi.org/10.1177/1356766711420838

Banyan Tree Hotels, \& Resorts. (2011). School of Hotel and Tourism Management at The Hong Kong Polytechnic University and Banyan Tree Hotels and Resorts INK MOUs to collaborate on executive education, research and internship programmes. Retrieved from http://www.banyantree.com/press_releases/school_of_hotel_and_tourism_management_at_the_hong_kong _polytechnic

Baron, R., \& Kenny, D. (1986). The moderator-mediator variable distinction in social psychological research: Conceptual, strategic, and statistical considerations. Journal of Personality and Social Psychology, 51, 1173-1182. http://dx.doi.org/10.1037//0022-3514.51.6.1173

Bennett, P. D., \& Harrell, G. D. (1975). The role of confidence in understanding and predicting buyers' attitudes and purchase intentions. The Journal of Consumer Research, 2(2), 110-117. http://dx.doi.org/10.1086/208622

Berry, L. L. (2000). Cultivating service brand equity. Academy of Marketing Science Journal, 28(1), 128-137. http://dx.doi.org/10.1177/0092070300281012

Bharadwaj, S. G., Varadarajan, P. R., \& Fahy, J. (1993). Sustainable competitive advantage in service industries: A conceptual model and research propositions. Journal of Marketing, 57(4), 83-99. http://dx.doi.org/10.2307/1252221

Biel, A. L. (1991). The brandscape: Converting image into equity. Admap, 10, 41-46.

Bluemelhuber, C., Carter, L. L., \& Lambe, C. J. (2007). Extending the view of brand alliance effects. International Marketing Review, 24(4), 427-443. http://dx.doi.org/10.1108/02651330710761008

Boulding, W., Kalra, A., Staelin, R., \& Zeithaml, V. A. (1993). A dynamic process model of service quality: From expectations to behavioral intentions. Journal of Marketing Research, 30(1), 7-27. http://dx.doi.org/10.2307/3172510

Boush, D. M., \& Loken, B. (1991). A process-tracing study of brand extension evaluation. Journal of Marketing Research, 28(1), 16-28. http://dx.doi.org/10.2307/3172723

Bouten, L. M., Snelders, D., \& Hultinkand, E. J. (2011). The impact of fit measures on the consumer evaluation of new co-branded products. Journal of Product Innovation Management, 28(4), 455-469. http://dx.doi.org/10.1111/j.1540-5885.2011.00819.x

Brady, Michael, K., Bourdeau, Brian, L., \& Heskel, Julia. (2005). The importance of brand cues in intangible service industries: An application to investment services. The Journal of Services Marketing, 19(6/7), 401-410. http://dx.doi.org/10.1108/08876040510620175

Campbell, D. R., \& Donald, W. F. (1959). Convergent and discriminant validation by the multitrait-multimethod matrix. Psychological Bulletin, 56, 81-105. http://dx.doi.org/10.1037/h0046016

Cornelis, P. C. M. (2010). Effects of co-branding in the theme park industry: a preliminary study. International 
Journal of Contemporary Hospitality Management, 22(6), 775-796. http://dx.doi.org/10.1108/09596111011063089

Dickinson, S. J., \& Barker, A. (2007). Evaluations of branding alliances between non-profit and commercial brand partners: the transfer of affect. International Journal of Nonprofit and Voluntary Sector Marketing, 12(1), 75-89. http://dx.doi.org/10.1002/nvsm.291

Dickinson, S. J., \& Heath, T. (2006). A comparison of qualitative and quantitative results concerning evaluations of co-branded offerings. Journal of Brand Management, 13(6), 393-406. http://dx.doi.org/10.1057/palgrave.bm.2540281

Dickinson, S. J., \& Heath, T. (2008). Cooperative brand alliances: How to generate positive evaluations. Australasian Marketing Journal, 16(2), 22-38. http://dx.doi.org/10.1016/S1441-3582(08)70012-0

Farquhar, P. H. (1994). Strategic challenges for branding. Marketing Management, 3(2), 8-15.

Fazio, R. H. (1986). How do attitudes guide behavior? New York: The Handbook of Motivation and Cognition, Guilford Press.

Fazio, R. H., Powell, M. C., \& Williams, C. J. (1989). The role of attitude accessibility in the attitude-to-behavior process. The Journal of Consumer Research, 16(3), 280-288. http://dx.doi.org/10.1086/209214

Guillet, B. D., \& Tasci, A. D. A. (2010). Travelers's takes on hotel-restaurant co-branding: Insights for China. Journal of Hospitality \& Tourism Research, 34(2), 143-163. http://dx.doi.org/10.1177/1096348009350618

Hair, F. J., Anderson, E. R., Tatham, L.R., \& Black, C. W. (2010). Multivariate Data Analysis (7 ${ }^{\text {th }}$ ed.). New Jersey: Prentice Hall International.

Haugtvedt, C. P., Leavitt, C., \& Schneier, W. L. (1993). Cognitive strength of established brands: memory, attitudinal and structural approaches. In Aaker D \& Biel A (Eds.). Brand Equity and Advertising: The Role of Advertising in Creating Brand Equity. Hillsdale, NJ: Lawrence Erlbaum.

Helmig, B., Huber, J., \& Leeflang, P. (2007). Explaining behavioural intentions toward co-brand products. Journal of Marketing, 23(3/4), 285-304. http://dx.doi.org/10.1362/026725707X196387

Hong Kong Hotels Association. (2009). Annual report 2008/09-Executive Director's Review. Retrieved from http://www.hkha.org/internal/hkha_2/news024.htm

Hoyer, W. D., \& Brown, S. P. (1990). Effects of brand awareness on choice for a common, repeat-purchase product. The Journal of Consumer Research, 17(2), 141-148. http://dx.doi.org/10.1086/208544

James, D. O. (2005). Guilty through association: brand association transfer to brand alliances. The Journal of Consumer Marketing, 22(1), 14-24. http://dx.doi.org/10.1108/07363760510576518

Johnson, E. J., \& Russo, J. E. (1984). Product familiarity and learning new information. The Journal of Consumer Research, 11(1), 542-550. http://dx.doi.org/10.1086/208990

Keller, K. L. (1993). Conceptualizing, measuring, and managing customer-based brand equity. Journal of Marketing, 57(1), 1-22. http://dx.doi.org/10.2307/1252054

Keller, K. L., \& Aaker, D. A. (1992). The effects of sequential introduction of brand extensions. Journal of Marketing Research, 29(1), 35-50. http://dx.doi.org/10.2307/3172491

Keller, P. A., \& McGill, A. L. (1994). Differences in the relative influence of product attributes under alternative processing conditions: Attribute importance versus attribute ease of imagability. Journal of Consumer Psychology, 3(1), 29-49. http://dx.doi.org/10.1016/S1057-7408(08)80027-7

Kwun, D. J. W., \& Oh, H. (2007). Consumers' evaluation of brand portfolios. International Journal of Hospitality Management, 26(1), 81-97. http://dx.doi.org/10.1016/j.ijhm.2005.09.003

Lafferty, B. A., \& Goldsmith, R. E. (1999). Corporate credibility's role in consumers' attitudes and purchase intentions when a high versus a low credibility endorser is used in the ad. Journal of Business Research, 44(2), 109-116. http://dx.doi.org/10.1016/S0148-2963(98)00002-2

Lafferty, B. A., \& Goldsmith, R. E. (2003). Cause-brand alliances: Does the cause help the brand or does the brand help the cause? Journal of Business Research, 58(2005), 423-429. http://dx.doi.org/10.1016/j.jbusres.2003.07.001

Lafferty, B. A., Goldsmith, R. E., \& Hult, G. T. M. (2004). The impact of the alliance on the partners: a look at 
cause-brand alliances. Psychology and Marketing, 21(7), 509-531. http://dx.doi.org/10.1002\%2Fmar.20017

Lanseng, E. J., \& Olsen, L. E. (2012). Brand alliances: The role of brand concept consistency. European Journal of Marketing, 46(9), 1108-1126. http://dx.doi.org/10.1108/03090561211247874

Liu, M. T., Chu, R., Wong, I. A., Zúñiga, M. A., Meng, Y., \& Pang, C. (2012). Exploring the relationship among affective loyalty, perceived benefits, attitude, and intention to use co-branded products. Asia Pacific Journal of Marketing and Logistics, 24(4), 561-582. http://dx.doi.org/10.1108/13555851211259025

Low, G. S., \& Lamb, C. W. (2000). The measurement and dimensionality of brand associations. The Journal of Product and Brand Management, 9(6), 350-368. http://dx.doi.org/10.1108/10610420010356966

Mitchell, Andrew, A., Olson, \& Jerry, C. (1981). Are product attribute beliefs the only mediator of advertising effects on brand attitude? Journal of Marketing Research, 18(3), 318-332. http://dx.doi.org/10.2307/3150973

Onkvisit, Sak, \& Shaw, John, J. (1989). Service marketing: Image, branding, and competition. Business Horizons, 32(1), 13-18. http://dx.doi.org/10.1016/0007-6813(89)90018-9

Park, C. W., Jun, S. Y., \& Shocker, A. D. (1996). Composite branding alliances: An investigation of extension and feedback effects. Journal of Marketing Research, 33(4), 453-466.

Park, C. W., \& Lessig, V. P. (1981). Familiarity and its impact on consumer decision biases and heuristics. The Journal of Consumer Research, 8(2), 223-231. http://dx.doi.org/10.1086/208859

Rao, A. R., Qu, L., \& Ruekert, R. W. (1999). Signaling unobservable product quality through a brand ally. Journal of Marketing Research, 36(2), 258-268. http://dx.doi.org/10.2307/3152097

Rao, A. R., \& Ruekert, R. W. (1994). Brand alliances as signals of product quality. Sloan Management Review, 36(1), 87-97.

Robert, P. W., \& Dowling, G. R. (2002). Corporate reputation and sustained superior financial performance. Strategic Management Journal, 23, 1077-1093. http://dx.doi.org/10.1002/smj.274

Rodrigue, C. S., \& Biswas, A. (2004). Brand alliance dependency and exclusivity: an empirical investigation. Journal of Product \& Brand Management, 13(7), 477-487. http://dx.doi.org/10.1108/10610420410568417

Roedder, J. D., Loken, B., \& Joiner, C. (1998). The negative impact of extensions: Can flagship products be diluted? The Journal of Marketing, 62(1), 19-32.

Santoro, M. (2000). Success breeds success: the linkage between relationship intensity and tangible outcome in industry-university collaboration ventures. The Journal of High Technology Management Research, 11(2), 255-273.

Simonin, B. L., \& Ruth, J. A. (1998). Is a company known by the company it keeps? Assessing the spillover effects of brand alliances on consumer brand attitudes. Journal of Marketing Research, 35(1), 30-42. http://dx.doi.org/10.2307/3151928

Standifird, S. S. (2005). Reputation among peer academic institutions: An investigation of the US news and world report's ranking. Corporate Reputation Review, 8(3), 233-244. http://dx.doi.org/10.1057/palgrave.crr.1540252

The Chinese University of Hong Kong. (2001). CUHK launches the first teaching hotel in Hong Kong. Retrieved from http://www.cuhk.edu.hk/ipro/pressrelease/011219e.htm

Washburn, J. H., Till, B. D., \& Priluck, R. (2000). Co-branding: Brand equity and trial effects. Journal of Consumer Marketing, 17(7), 591-604. http://dx.doi.org/10.1108/07363760010357796

Zeithaml, V. A. (1988). Consumer perceptions of price, quality, and value: A means-end model and synthesis of evidence. Journal of Marketing, 52(3), 2-22. http://dx.doi.org/10.2307/1251446 